\title{
An Analysis of Value-Added of Seaweed Products as An Efforts to Improve Public Welfare in Bantaeng District
}

\author{
Soraya Ramadani ${ }^{1}$, Hamzah ${ }^{2}$, Sitti Fakhriyyah ${ }^{3}$
}

\author{
${ }^{1}$ Fisheries Science, Faculty of Marine and Fisheries Science, Hasanuddin University, Perintis Kemerdekaan St.Km 10, Makassar 90245 , \\ Indonesia \\ ${ }^{2,3}$ Department of Fisheries Science, Faculty of Marine and Fisheries Science, Hasanuddin University, PerintisKemerdekaan St Km 10 , \\ Makassar 90245, Indonesia
}

\begin{abstract}
This study aims to quantify the revenue and analyze the value-added seaweed crackers product of SMEs A and SMEs B in Bantaeng District by using the income formula and the value-added revenue method. The results shows that SMEs A gains higher revenues amounted IDR 1.618.862 than SMEs B, which get the most revenue IDR. 885.250. It is influenced by the type of product, activities production, capital, and marketing. Meanwhile, the ratio of the value-added of SMEs A was also higher by $91.30 \%$, with a profit rate of $98.54 \%$ compared to $88.43 \%$ for SMEs B by a margin of $98.43 \%$. It can be assumed that the seaweed cracker business can improve the incomes and public welfare in Bantaeng.
\end{abstract}

Keywords-products, seaweed, value-added, SMEs, production.

\section{INTRODUCTION}

Seaweed is one of the leading commodities that have an attraction to be cultivated because it is simple and has a competitive market in the world. The seaweed demand increases in every year. The use of seaweed is also more extensive and varied due to increased knowledge of the commodity. At a time in the past, the process of seaweed only from post-harvest handling to drying. Meanwhile, nowadays, the empowerment and development of the seaweed can be re-processed into new products (Suryawati, 2017)

Changing seaweed into new products of higher economic value, it will be able to provide value-added due to the issuance costs of forming new higher prices and profits more excellent than without treatment processes. Seaweed so that the value-added would be higher than unprocessed seaweed It has excellent prospects mainly carried out during the production of seaweed is abundant and low price (Rahman, 2015).

Value added is increasing the price of the product because the functional input given on the product concerned. This input relates to the process of transformation of raw materials to the storage. This added value can be analyzed through the methods of calculation to estimate changes in the value of raw materials after getting treatment. Values obtained are the excess of the product's value with the cost of raw materials and other inputs (Hayami, 1987).

The term added value in line with the macro-economic concepts related to national income calculations using measurements productive. The meaning of value-added here is the difference between the output value of a business, the total revenue from sales, and the costs used to manufacture these products. This value can be determined from the difference between the input's value and the output of the business (Haller \& Stolowy, 1995).

The added value of the seaweed can create distinctiveness of an area through culinary offerings. Seaweed can be developed into various types of derivative products with high health value. One is the seaweed crackers. Are made from seaweed that has an existence to develop. The culinary offerings in the field of business are very promising. They include business areas that will not be endless because, in everyday human life, is always associated with consumption. Seaweed crackers, especially high nutritional value that is expected to be a special place in the hearts of the people (Ernawati, 2020).

The existence of innovation in making crackers is one crucial strategy in increasing sales volume. It can provide value-added of an existing product and provides better 
solutions for consumers in selecting products. In buying a product, consumers do not merely look at the value or function of a product that needs it, but consumers also pay attention to whether the selected products add value or advantages compared with other similar products. It can be said that innovation is a decisive factor in the competitive industry and is a formidable weapon to face the competition. It can be reflected that winning the competition increased sales volume, which means improving coIDRorate profits, so the company's continuity can be assured. Conversely, if the company cannot innovate then able to make products that are misaligned (Russell, 1996)

Based on the description above, this study aims to determine how much revenue and value-added of crackers seaweed on Micro, Small, and Medium EnteIDRrises (SMEs) in Bantaeng Districts. Bantaeng has abundant raw materials potential of seaweed to be processed into crackers. This study's results are expected to provide input and suggestions as well as business opportunities that promise to increase social welfare in Bantaeng.

\section{RESEARCH METHODS}

The study was conducted in two Districts Bantaeng on SMEs. The research was conducted in November 2019 until February 2020. Primary data is obtained directly from the source and researched through interviews and surveys (questionnaires) with seaweed crackers businesses. A method of selecting respondents SMEs and MSMEs B was puIDRosive with consideration of business units that are still active in seaweed processing until the time of the study. The level of income can be used as a reference comparison. This study used two analyzes is the analysis of income and value-added analysis.

\section{RESULTS \& DISCUSSION}

\section{Revenue SMEs Crackers Seaweed}

Revenue is the output of an entire amount of income received by a person as remuneration on the results of the efforts initiated. The aim of building a business is to generate revenue, which can be used for personal and business survival pioneered. The higher the income, the greater the potential for businesses to finance spending and business activity.

One of the essential things in running a business is the cost of production. The production is the total of all fees that are used from production to marketing preparation. In Table 2 are presented the total revenue earned SMEs SMEs $\mathrm{A}$ and $\mathrm{B}$ as follows.

\begin{tabular}{ccccc}
\hline SMEs & Product & $\begin{array}{c}\text { Revenue } \\
\text { (TR)(Rp) }\end{array}$ & $\begin{array}{c}\text { Cost } \\
\text { (TC) (Rp) }\end{array}$ & $\begin{array}{c}\text { Income } \\
\text { (TR-TC) (Rp) }\end{array}$ \\
\hline $\mathbf{A}$ & $\begin{array}{c}\text { Cheeses } \\
\text { Stick }\end{array}$ & 1.083 .000 & 198.084 & 885.250 \\
\hline $\mathbf{B}$ & $\begin{array}{c}\text { Chesses } \\
\text { Paper }\end{array}$ & 1.966 .000 & 347.471 & 1.618 .862 \\
& & & & \\
\hline
\end{tabular}

Fig 1. Average monthly Revenue During the Month (November to January) Crackers Seaweed Production

The table above shows that the average monthly income crackers A cheese sticks on SMEs were lower by IDR.885.250, compared to crackers cheese paper on SMEs B amounting IDR.1.618.862. From the research results obtained show that first, there is the influence of the product on the level of revenues-cheese crackers paper products preferred by the community. The second result showed that there are significant factors of production to the level of revenues. SMEs B performs an average of eight times the production in one month. At the same time, SMEs A does Ra on average three times the production in one month.

The third result shows that there is a significant capital factor in the level of revenues. Capital is referred to here as a material to conduct production activities, paid labor, and other costs. The results showed that there are four significant marketing factors on the level of revenues. SMEs B markets their products over to the showroom as a marketing center with the goal of outsiders who visit Bantaeng, entrust the product to the store's, and market directly to consumers. Most buyers purchase products SMEs B directly by several agencies that conduct activities. Meanwhile, SMEs A market their products only to entrust to the showroom and shops nearby. It leads to a take to recover the capital used for production again.

\section{Calculation of the Value Added Production Seaweed Crackers}

The value-added analysis is an estimation of the raw material method with a special treatment to get the value. The added value is influenced by the technology used in the processing. The basis of calculation used is the added value per unit of the central raw material $\mathrm{kg}$. Tables valueadded analysis calculation results in seaweed cracker production in SMEs SMEs A and B are presented as follows 


\begin{tabular}{|c|c|c|c|}
\hline Variable & Calculation & SMEsA & SMEsB \\
\hline & & $\begin{array}{l}\text { Cheeses } \\
\text { Stick }\end{array}$ & Chesses Paper \\
\hline Output,Input, dan Pric & & & \\
\hline Output (kg) & A & 25 & 30 \\
\hline Raw Materials $(\mathrm{kg})$ & B & 1 & 1 \\
\hline Labor (HOK) & $\mathrm{C}$ & 1,125 & 1,125 \\
\hline Conversion Factor & $\mathrm{D}=\mathrm{A} / \mathrm{B}$ & 25 & 30 \\
\hline $\begin{array}{l}\text { Coefficient of Labor } \\
(\mathrm{HOK} / \mathrm{Kg})\end{array}$ & $\mathrm{E}=\mathrm{C} / \mathrm{B}$ & 1,125 & 1,125 \\
\hline Output Price $(\mathrm{Rp} / \mathrm{Kg})$ & $\mathrm{F}$ & 130.000 & 100.000 \\
\hline $\begin{array}{l}\text { Average Labor Wage } \\
(\mathrm{Rp} / \mathrm{HOK})\end{array}$ & G & 40.000 & 35.556 \\
\hline Revenues and Profit & & & \\
\hline $\begin{array}{l}\text { Raw Mateial Price } \\
(\mathrm{Rp} / \mathrm{Kg})\end{array}$ & $\mathrm{H}$ & 11.000 & 11.000 \\
\hline $\begin{array}{l}\text { Other Output Donation } \\
(\mathrm{Rp} / \mathrm{Kg})\end{array}$ & I & 365.000 & 250.000 \\
\hline Output Value ( $\mathrm{Rp} / \mathrm{Kg})$ & $\mathrm{J}=\mathrm{D}^{*} \mathrm{~F}$ & 3.250 .000 & 3.000 .000 \\
\hline Value Added $(\mathrm{Rp} / \mathrm{Kg})$ & $\mathrm{K}=\mathrm{J}-\mathrm{I}-\mathrm{H}$ & 2.874 .000 & 2.739 .000 \\
\hline ValueAdded Ratio(\%) & $\mathrm{L}=\mathrm{K} / \mathrm{J} * 100$ & 88,43 & 91,30 \\
\hline $\begin{array}{l}\text { Labor remuneration } \\
(\mathrm{Rp} / \mathrm{Kg})\end{array}$ & $\mathrm{M}=\mathrm{E}^{*} \mathrm{G}$ & 45,000 & 40.000 \\
\hline Part of Labor (\%) & $\mathrm{N}=\mathrm{M} / \mathrm{K} * 100$ & 1,57 & 1,46 \\
\hline Profit $(\mathrm{Rp} / \mathrm{Kg})$ & $\mathrm{O}=\mathrm{K}-\mathrm{M}$ & 2.829 .000 & 2.699 .000 \\
\hline Profitability (\%) & $\mathrm{P}=0 / \mathrm{K} * 100$ & 98,43 & 98,54 \\
\hline Reply Services for Proc & luction Factor & & \\
\hline$\overline{\text { Margin }(\mathrm{Rp} / \mathrm{Kg})}$ & $\mathrm{Q}=\mathrm{J}-\mathrm{H}$ & 3.239 .000 & 2.989 .000 \\
\hline Profit $(\%)$ & $\mathrm{R}=\mathrm{O} / \mathrm{Q}^{*} 100$ & 87,34 & 90,30 \\
\hline Labor $(\%)$ & $\mathrm{S}=\mathrm{M} / \mathrm{Q}^{*} 100$ & 1,39 & 1,34 \\
\hline Other Input (\%) & $\mathrm{T}=\mathrm{I} / \mathrm{Q}^{*} 100$ & 11,27 & 8,36 \\
\hline
\end{tabular}

Fig 2. Table Calculation of Value Added

From the table above shows that the value of the conversion factor on crackers cheese sticks at 25 . The value of a factor on paper cheese crackers at 30 . The number of Working People's Day (HOK) in the processing of cheese sticks crackers and Papercheese crackers amounted to $1.125 \mathrm{HOK}$ to cultivate seaweed as $1 \mathrm{~kg}$. The coefficient of employment in SMEs and MSMEs A is the same B of $0.75 \mathrm{HOK} / \mathrm{kg}$. The average wage for labor in the manufacture of cheese sticks crackers of IDR.26.667 per HOK, and the paper cheese crackers amounted to 20,000 per HOK.

In the manufacture of cheese sticks crackers have other input contribution amounting to IDR $365.000 / \mathrm{kg}$, and on paper cheese crackers have other input amounting to IDR250,000/ kg. The output value in the manufacture of crackers or cheese sticks crackers is IDR 3.250 .000 or $88.43 \%$, while the paper cheese crackers are IDR 3.000 .000 or $91.30 \%$ for $1 \mathrm{~kg}$ of seaweed. The value-added on cheese sticks crackers is IDR.2.874.000, while paper cheese crackers are IDR 2.739 .000 with equal to $1 \mathrm{~kg}$ of seaweed.

Labor costs in cheese stick crackers are IDR 200.00, the profit level is $93.04 \%$ and the margin is IDR 3,239 million for $1 \mathrm{~kg}$ of seaweed. While the labor costs in cheese paper crackers are IDR 250,000, the profit rate is $90.87 \%$ and the margin is IDR $2,989,000$ for $1 \mathrm{~kg}$ of seaweed.

\section{CONCLUSION}

SMEs B has a higher revenue of IDR 1.618 .862 compare to SMEs A, which only has IDR885.250 of the revenue. It is influenced by the type of product, production factors, capital factors, and marketing factors.

For added value generated by the paper cheese crackers on SMEs B is IDR.2.739.000 for $1 \mathrm{~kg}$ of seaweed with a gain of IDR.2.989.000, whenever the production process. As for the value-added generated by crackers, cheese sticks on SMEs A is IDR.2.874.000 for $1 \mathrm{~kg}$ of seaweed with a gain of IDR.3.239.000 whenever the production process.

Suggestions can be applied based on the above results is related institutions can perform the following activities as a form of follow-up measures for efforts to optimize product development seaweed crackers in Bantaeng

1. Building market access to increase the demand for cracker products outside Bantaeng constrained transportation away

2. Building business partnership pattern that allows access capital to increase production so the business capacity is more optimal.

3. Encourage Marine and Fisheries Agency's commitment to guiding businesses to a group formed to stand independently.

\section{REFERENCES}

[1] Djahidin, 1985. Financial Statement Analysis. Ghalia Indonesia, Jakarta. Jumingan, 2006. Financial Statement Analysis. Bumi Aksara, Jakarta

[2] Ernawati, C. (2020). Crackers existence Wet For Culinary Kapuas Hulu. Proceedings of the National Seminar on Educational Anthropology (SENASPA), Vol. 1, 133 - 141.

[3] Haller, A., \& Stolowy, H. (1995). Value Added Accounting in Germany and France: A Conceptual and Empirical Comparison. Annual Congress of the European Accounting Association (pp. Of conference proceedings). Birmingham, United Kingdom: May 10-2. campus.hec.fr

[4] Hayami, Y., Kawagoe, T., Morooka, Y., \& Siregar, M. (1987). Agricultural Marketing and Processing in Java Upland A Perspective From A Sundanese Village. Bogor: CPGRT Center

[5] Khairani, S., \& Pratiwi, R. (2018). Turnover Increased Sales Through Diversification and Promotion Strategy In Palembang Typical Souvenir Craft SMEs. Journal of Community Services, 36-43 
[6] Langitan, 1994. Analysis of Value Added Products Soy Milk Refreshments. Department of Social Economics of Agriculture, IPB Bogor

[7] Mane, A., \& Menne, F. (2017). Seaweed Farmers Family Empowerment in Rural Pa'jukukang To Increase Revenue. XVII edition of the journal Research Unibos Makassar, 1-17

[8] Sugama, Ketut. 2013. Aquaculture Development Opportunities crab shell is soft To Increase Community Income Nangro Aceh Darussalam province. Presentation Material. Banda Aceh September 6th 2013

[9] Suryawati, S. H., \& Erlina, M. D. (2017). Business Development Strategy Seaweed Cultivation in South Buton District. J. Socio-Economic KP Vol. 12 No. 1, 31-44

[10] Rahman, S. (2015). Analysis of the Value Added Agroindustri Corn Chips. Journal of Food Technology Application 4 (3), 108-111

[11] C Russel, R., \& Taylor, B. (1996). Production and Operations Management: Focusing on Quality and Competitiveness. New Jersey: Prentice Hall 